\title{
Analysis of Arsenic in Rice in Medan, North Sumatera Indonesia by Atomic Absorption Spectrophotometer
}

\author{
EVI EKAYANTI GINTING ${ }^{1 *}$, JANSEN SILALAHI ${ }^{2}$ and EFFENDY DELUX PUTRA ${ }^{3}$ \\ ${ }^{1,2,3}$ Department of Pharmacy, Faculty of Pharmacy, University Sumatera Utara, Medan-20155, Indonesia. \\ ${ }^{*}$ Corresponding author E-mail: eviginting11@gmail.com \\ http://dx.doi.org/10.13005/ojc/340557
}

(Received: June 14, 2018; Accepted: August 21, 2018)

\begin{abstract}
Arsenic is a toxic element even at low concentration, therefore its presence in rice is a matter of concern for the public health safety. Several studies have reported that rice contain arsenic at high levels. Rice is the staple food in Indonesia with high consumption around $200-300 \mathrm{~g} /$ day/person, but the investigations on arsenic content in rice has never been done. The aim of this study was to analyze arsenic in rice commonly consumed in Medan. Samples were obtained from 4 traditional markets and analyzed by atomic absorption spectrophotometer. The highest arsenic concentrations were found in inorganic red rice $3.71 \mathrm{mg} / \mathrm{kg}$; organic brown rice $3.40 \mathrm{mg} / \mathrm{kg}$; inorganic white rice $0.33 \mathrm{mg} / \mathrm{kg}$; and organic black rice $0.13 \mathrm{mg} / \mathrm{kg}$. The results of study have shown that the levels of arsenic in rice vary widely and maybe harmful.
\end{abstract}

Keyword: Arsenic, Rice, Medan, Atomic Absorption Spectroscopy.

\section{INTRODUCTION}

Arsenic is one of the most toxic metals found in nature because it can cause toxicity and carcinogenicity, even at low concentration. Longterm exposure may lead to an increased risk for various cancers, carcinoma including skin cancer, bladder, lung, kidney, liver, and prostate. ${ }^{1}$ Arsenic can be found in water, air, food, and soil including from volcanic eruptions, contamination from mines, the use of pesticides and fertilizers. According to the International Agency for Research on Cancer (IARC), arsenic is included in the first class as a carcinogenic substance and may cause lung, skin and bladder cancer in humans without a minimum threshold value in which small amounts of arsenic can be harmful to human health. ${ }^{2}$

Rice is a staple food that is widely consumed around the world, especially in Asia. Indonesia is the country with the second largest rice consumption in the world after Bangladesh. Based on the Badan Pusat Statistik (2017) that the amount of rice consumption in Indonesia is 200-350 g/day/ person. Food Drug Administration United State from 2012 to 2013 from 200 samples of rice and rice products, found that the higher content of arsenic found in brown rice compared to white rice. It was reported that the total content of all rice circulating in the United States, contain arsenic with various 
levels ranging from $17.1 \mu \mathrm{g} / \mathrm{kg}$ in white rice and the highest level in red rice $963 \mu \mathrm{g} / \mathrm{kg} .^{3}$ The JOINT FAO / WHO Expert Committee on Food Addictives (JECFA, 2011) also reported that rice is the main source of arsenic exposure for humans today. Food is a potential way of exposure to arsenic and arsenic in rice is associated with soil contamination, fertilization, and pesticide use. Hence, (for this reason) the content of arsenic in food especially in rice has become a global concern. ${ }^{4}$

According to the American Environmental Protection Agency, rice is not the only source of arsenic-containing foods, some vegetables, fruits, and water may contain arsenic, but arsenic levels in brown rice are not at a safe level. The European Food Safety Authority (2010) reported that rice is the main source of arsenic-containing foods in European countries. Water used to cook rice contributes to the addition of arsenic in rice. While the process of cleaning and cooking rice, is not an effective way to remove arsenic in rice, this process only reduces the arsenic content to a maximum of 10 to $20 \%$ of the total arsenic contained in the rice..$^{5-6}$

Determination of arsenic in rice and food has been widely practiced around the world and the results obtained show an alarming level of arsenic for public health because it exceeds the WHO standard limit (2014) that is $0.3 \mathrm{mg} / \mathrm{kg}$. In Indonesia there has never been done on arsenic content in rice, especially there is no regulation and standards set by BPOM Republic of Indonesia. The aim of this study was to analyze arsenic levels in rice circulating in the city of Medan, the rice from traditional markets and supermarkets.

\section{EXPERIMENTAL}

\section{Sample Acquisition}

Sample acquisition method was conducted by purposive sampling, which the samples were obtained from different markets around Medan to represent the rice commonly consumed by people. ${ }^{7}$ Sample were obtained from 4 traditional Markets in Medan were Pasar Sore Padang Bulan, Pasar Simpang Limun, Pasar Sei Sikambing, Pasar Besar Berastagi and 2 Supermarkets were Berastagi and Carrefour. A total of 20 rice samples consisted 11 white rice (2 organic and 9 inorganic), 3 brown rice
(1 organic and 2 inorganic), 5 red rice (1 organic and 4 inorganic), 1 black rice (organic).

\section{Research Location and Time}

The analyses of the samples were conducted at Laboratory of Agro Industry Center, Bogor, West Java, Indonesia from 25th June to $5^{\text {th }}$ November 2017.

\section{Tools}

Tools used in this research were microwave (SCP Science), label paper, blender, Whatmann No. 41 filter paper, analytical balance (Mettler Toledo), an Atom Absorption Spectrophotometer (GBC 906AA) with an argon-air flame with arsenic cathode lamps.

\section{Materials}

Materials used in this research were distilled water and quality materials proanical output of E. Merck namely, nitrat acid $65 \%$, hydrochloride acid $37 \%$, the AAS for arsenic standard solution at $1000 \mu \mathrm{g} / \mathrm{mL}$.

\section{Arsenic Analysis in Rice}

Rice were washed with water and dried. Rice were milled using a blender or grinder. Rice sample of $0.5 \mathrm{~g}$ was transferred into a microwave vessel, added $5 \mathrm{~mL}$ of $\mathrm{HNO}_{3}$ and $3 \mathrm{~mL} \mathrm{HCl}$. Then vessels were inserted in a microwave at a temperature of $180^{\circ} \mathrm{C}$ for $30 \mathrm{~min}$. until complete destruction indicated by the presence of clear liquid. Then the destruction results were cooled and included in a $50 \mathrm{~mL}$ measuring flask fed with distilled water and filtered with Whatmann no 41 paper. Then the solution was measured using an atomic absorption spectrophotometer at a wavelength of $193.7 \mathrm{~nm} .7$

\section{Calibration Curve}

Tenmililiters of $1000 \mu \mathrm{g} / \mathrm{mL}$ of arsenic standard solution was pipetted into a $100 \mathrm{~mL}$ well formed flask and added distilled water. Then $5 \mathrm{~mL}$ of the solution was transferred into a $500 \mathrm{~mL}$ flash, then diluted with distilled water to prepare $1 \mu \mathrm{g} / \mathrm{mL}$ arsenic standard solution then it was pipetted 0.5 , $1,1.5,2,2.5 \mathrm{~mL}$ into a $100 \mathrm{~mL}$ flash and this is as arsenic standard solution was used.

Arsenic Level $(\mathrm{mg} / \mathrm{kg})=\frac{\mathrm{X}(\mu \mathrm{g} / \mathrm{mL}) \times \mathrm{V}(\mathrm{mL}) \times \mathrm{Fp}}{\mathrm{W}(\mathrm{g})}$ 
$\mathrm{X}=$ concentration of analyte in sample solution; $\mathrm{V}=$ total volume of sample solution examined

$\mathrm{Fp}=$ Dilution factor of the decomposition results; $\mathrm{W}=$ Weight of sample

\section{RESULTS AND DISCUSSION}

The levels of arsenic in different analyzed rice samples presented in Table 1, Table 2 and Figure 1.

From the 20 samples of rice consisting of 11 white rice contain arsenic levels vary widely. The highest arsenic content of $0.33 \mathrm{mg} / \mathrm{kg}$ is found in non-organic white rice, where as the arsenic is still WHO $0.3 \mathrm{mg} / \mathrm{kg}$. From 11 white rice is below the level of $0.3 \mathrm{mg} / \mathrm{kg}$, and the lowest arsenic level $0.0071 \mathrm{mg} / \mathrm{kg}$, contained in organic white rice. Research conducted by the United State Department of Agriculture (USDA) (2010), reported that of $76 \%$ of white rice in the United States arsenic levels in non-organic white rice is higher than organic white rice. ${ }^{9}$ Organic Trade Association USA (2015) states that rice organics have lower arsenic levels than inorganic rice and arsenic levels with much more inorganic types in an environment where rice is grown than organic arsen. ${ }^{10}$

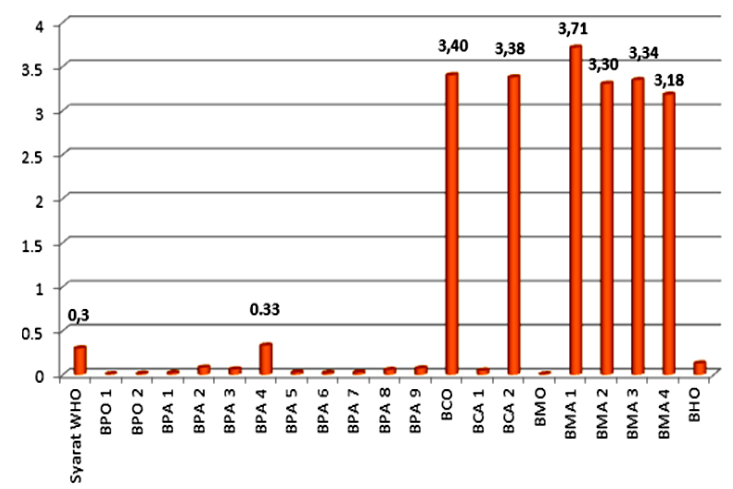

Fig. 1. Arsenic levels in Rice

Of the 9 color rice consisting of 3 brown rice, 5 red rice and 1 black rice obtained $3.7137 \mathrm{mg} /$ $\mathrm{kg}$ the highest arsenic levels were found in inorganic red rice and there were 5 rice with high arsenic levels

Table 1: Arsenic Levels in Analyzed Rice Samples marketed in Medan

\begin{tabular}{|c|c|c|c|c|}
\hline No. & Rice & Brand Name & Market of Sample collection & Arsenic Level (mg/kg) \\
\hline 1 & Organic & $\begin{array}{l}\text { Export Quality } \\
\text { Rice Organik }\end{array}$ & Swalayan Berastagi & 0,0071 \\
\hline 2 & Organic & $\begin{array}{l}\text { Diabetes Holistik } \\
\text { Super Organik }\end{array}$ & Swalayan Berastagi & 0,0117 \\
\hline 3 & Inorganic & $\begin{array}{c}\text { Rice Tani } \\
\text { Makmur Indosiar }\end{array}$ & $\begin{array}{c}\text { Pasar } \\
\text { Simpang Limun }\end{array}$ & 0,0192 \\
\hline 4 & Inorganic & $\begin{array}{l}\text { Rice Cap } \\
\text { Jambu Air }\end{array}$ & $\begin{array}{c}\text { Pasar } \\
\text { Simpang Limun }\end{array}$ & 0,0818 \\
\hline 5 & Inorganic & $\begin{array}{l}\text { Rice Kuku Balam } \\
\text { Super Berdikari } 21\end{array}$ & $\begin{array}{c}\text { Pasar } \\
\text { Simpang Limun }\end{array}$ & 0,0604 \\
\hline 6 & Inorganic & Rice Arias Aladin & $\begin{array}{l}\text { Pasar Sore } \\
\text { Padang Bulan }\end{array}$ & 0,3316 \\
\hline 7 & Inorganic & Rice Arwana & $\begin{array}{l}\text { Pasar Sore } \\
\text { Padang Bulan }\end{array}$ & 0,0243 \\
\hline 8 & Inorganic & - & $\begin{array}{l}\text { Pasar Besar } \\
\text { Berastagi }\end{array}$ & 0,0191 \\
\hline 9 & Inorganic & - & $\begin{array}{l}\text { Pasar Besar } \\
\text { Berastagi }\end{array}$ & 0,0248 \\
\hline 10 & Inorganic & $\begin{array}{l}\text { Rice Amco Gandapura } \\
\text { (Beras IR 64) }\end{array}$ & $\begin{array}{l}\text { Pasar Sei } \\
\text { Sikambing }\end{array}$ & 0,0548 \\
\hline 11 & Inorganic & Rice IR 64 SM & $\begin{array}{l}\text { Pasar Sei } \\
\text { Sikambing }\end{array}$ & 0,0720 \\
\hline
\end{tabular}


exceeding WHO $0.3 \mathrm{mg} / \mathrm{kg}$. In brown rice which highest is organic brown rice $3.4010 \mathrm{mg} / \mathrm{kg}$ and arsenic levels in inorganic black rice $0.1283 \mathrm{mg} / \mathrm{kg}$. Of the 9 samples of colored rice, the lowest levels of arsenic were found in organic red rice $0.0061 \mathrm{mg} / \mathrm{kg}$.

The difference of arsenic levels of organic and inorganic white rice is due to the way of planting and the process during rice growth, ranging from the use of pesticides, fertilizers, water for irrigation, as well as land where rice grows. ${ }^{11-13}$ The level of arsenic in rice also depends on the color of rice, which is white or colored rice, organic or inorganic, and where the growth of rice. ${ }^{14-15}$ Research conducted in some countries, if the level of arsenic in water used for irrigation and land where the rice is grown in the country is low then the arsenic in rice is also low, otherwise it is closely related to other words where the environment of rice grow has been contaminated by arsenic and differences in varieties of rice also cause differences in arsenic levels. ${ }^{16-17}$
From Table 1, 2 it can be seen that of the all rice at Medan, non-organic Red Rice is the highest arsenic content $(3.71 \mathrm{mg} / \mathrm{kg})$ put of 5 samples with 1 organic and 4 non-organic) than the highest arsenic content white rice $(0.33 \mathrm{mg} / \mathrm{kg})$ out of 11 samples with 2 organic and 9 non-organic), and the highest arsenic content in brown rice $(3.40 \mathrm{mg} / \mathrm{kg}$ ) out of 3 samples with 1 organic and 2 non-organic) and organic black rice contain only $0.13 \mathrm{mg} / \mathrm{kg}$ of the 20 rice samples, 6 rice samples contain arsenic that exceeded the level of $0.3 \mathrm{mg} / \mathrm{kg}$ or even 10 times higher than maximum level made by WHO. The results of this study must be a warning as serious concern because arsenic can cause cancer and high intake of rice in Medan. This can be a serious concern for the government and for next researcher it is suggested to importance of researching the source of arsenic intake from other foodstuffs so it is known the total amount of arsenic intake in Medan, Indonesia, community besides it is suggested to do research on factors influencing arsenic level in rice circulating in Medan City.

Table 2 : Arsenic Level in Color Rice in Medan

\begin{tabular}{|c|c|c|c|c|}
\hline \multirow{2}{*}{\multicolumn{5}{|c|}{ B Color Rice }} \\
\hline & & & & \\
\hline No. & Rice & Brand Name & Market of Sample collection & $\begin{array}{c}\text { Arsenic Leve } \\
(\mathrm{mg} / \mathrm{kg})\end{array}$ \\
\hline 1 & Organic & Bio Cell Organik (Non Pesticide) & Swalayan Berastagi & 34,010 \\
\hline 2 & Inorganic & - & Pasar Besar Berastagi & 0,0462 \\
\hline 3 & Inorganic & - & Pasar Besar Berastagi & 33,767 \\
\hline \multicolumn{5}{|c|}{ Red Rice } \\
\hline 4 & Organic & $\begin{array}{c}\text { Red Rice } \\
\text { Tropicana Slim }\end{array}$ & $\begin{array}{l}\text { Swalayan } \\
\text { Carrefour }\end{array}$ & 0,0061 \\
\hline 5 & Inorganic & $\begin{array}{l}\text { Red Rice } \\
\text { Berasku }\end{array}$ & $\begin{array}{l}\text { Pasar Sore } \\
\text { Padang Bulan }\end{array}$ & 37,136 \\
\hline 6 & Inorganic & $\begin{array}{l}\text { Rice Cantik } \\
\text { Manis } 1022\end{array}$ & $\begin{array}{l}\text { Pasar Sei } \\
\text { Sikambing }\end{array}$ & 33,030 \\
\hline 7 & Inorganic & $\begin{array}{c}\text { Red Rice } \\
\text { Matahari Harum }\end{array}$ & $\begin{array}{l}\text { Pasar Sei } \\
\text { Sikambing }\end{array}$ & 33,446 \\
\hline 8 & Inorganic & $\begin{array}{c}\text { Red Rice } \\
\text { Super Cantik } \\
\text { Manis }\end{array}$ & $\begin{array}{c}\text { Pasar Sore } \\
\text { Padang Bulan }\end{array}$ & 31,793 \\
\hline 9 & Organic & Black Rice Organic Hotel Grade & $\begin{array}{l}\text { Swalayan } \\
\text { Carrefour }\end{array}$ & 0,1283 \\
\hline
\end{tabular}

\section{CONCLUSION}

From this research, it is obtained the arsenic of various types rice at medan were 3.71 $\mathrm{mg} / \mathrm{kg}$ in Inorganic Red Rice, $0.33 \mathrm{mg} / \mathrm{kg}$ in Inorganic White Rice, $3.40 \mathrm{mg} / \mathrm{kg}$ in Organic Brown Rice and $0.13 \mathrm{mg} / \mathrm{kg}$ in Organic Black Rice. 


\section{ACKNOWLEDGEMENT}

The writer would like to express his sincere thanks to my Prof. Dr. Jansen Silalahi, M. App, Sc. Apt, as the first thesis supervisor, for his valuable suggestion and guidance during the course of this work, and to Prof. Dr. Rer. Nat. Effendy De Lux Putra, SU., Apt. under his help in estimation of this writing and valuable discussion.

\section{REFERENCES}

1. International Agency for Research on Cancer, Monographs on the Evaluation of the Carcinogenic Risks to Humans., 2014, 20.

2. International Agency for Research on Cancer, Monographs on the Evaluation of the Carcinogenic Risks to Humans., 2012, 23.

3. Food Drug Administration, USA, Arsenic in Rice and Rice Products Risk Assessment Report 2012., 2013.

4. JECFA, Evaluation of Certain Contaminants in Food., 2011.

5. Andrea, R.; Christian, B.; Joerg, F.; Andrew, A.M.; J. Environment. Monitoring., 2008, 11, 3.

6. Manus, C.; Xiao, J.; Julia, G.F.; Andrew, A. M.; Research Article., 2015, 10, 3.

7. Method Analysis Food, Indonesia National Agency of Drug and Food Control., 2012. 20, 57-61

8. Hamida, Khairuna, S.Zulaekah, Mutalazimah, Journal Kesehatan Masyarakat, Surabaya., 2012, 1, 1-2.

9. United State Departement of Agriculture (USDA), National Nutrient Database for
Standard Reference., 2010, 11-12.

10. Organic Trade Association, USA. Arsenic in Food and Agriculture., 2015, 1-3.

11. Baba, K.; Arao, T.; Maejima, Y.; Watanabe, E.; Eun, H.; Shizaka, M. L. J. Analys. Chem., 2008, 80, 16-17.

12. Bhattacharya, P.; Samal, A. C.; Majumdar, J.; Santra, S. C.; Banerjee, S.; (2013). India. J. Hazard. Mater., ,2013, 262, 38.

13. Diamond, G. D.; Cottingham, L. K.; Gruber, F. J.; Punshon, T.; Sayarath, V.; Gandolfi, J. A.; Baker, R. E.; Jackson, P. B.; Folt, L. C.; Karagas, R. M. J. Enviro. Sci., 2011, 108, 51-53.

14. William, P.N.; Price, A.H.; Raab, A.; Meharg, A. A. J. Enviro. Sci and Tech., 2005, 39, 15-16.

15. Norton, G. J.; Pinson, S. R.; Alexander, J. J. Agri. Food. Chem., 2012, 52, 9-10.

16. Meharg, A. A.; Rahman, M. M. J. Enviro. Sci. Tech., 2009, 37, 22-23.

17. Ilion, S.; Alessandrelli, M.; Cresti, R.; Forte, G.; Caroli, S. J. Microchem., 2010, 73, 1-3. 